\title{
Ádám Makkai: Polyglot Linguist, Poet and Literary Translator Between Languages
}

Special Dedication Essay

\section{Louise 0. Vasvári}

Adam Makkai was born in Budapest on December 16, 1935 into a Transylvanian family of writers, judges, and ministers of the Hungarian Reformed Church. He received his first two years of schooling in German before the war, while after the war he also learned Russian and French. At university, after a brief period studying law, he was for two years a French major but his studies were disrupted by the Revolution and he escaped to the West in 1956. He arrived to the U.S. on Jan 1, 1957 and was promptly admitted to Harvard University, where the following year he received his B. A. cum laude as a Russian major and French minor. From 1958-60, Makkai spent two years in Hawaii, where he was a teacher of German, Russian, French, and Latin. Subsequently he received a fellowship to Yale University, where he received his M.A. and Ph.D. in General Linguistics (1962, 1965), writing his Ph.D. dissertation on English idiom structure (published as a book in 1972).

Makkai spent the bulk of his academic career at the University of Illinois in Chicago (UIC), but with a number of fellowships (Fulbright, IREX) and visiting academic appointments elsewhere, including in Singapore and Hong Kong. Presently he is Professor Emeritus from UIC and residing in retirement in his beloved Hawaii, in Wainae, with his wife, Ágnes Arany, a writer, and they take regular trips to Hungary and to Transylvania. Makkai is the recipient of the Hungarian Kossuth Díj and numerous other awards, including the Presidential Gold Medal from the President of Hungary (1999) for his In Quest of the Miracle Stag, to be discussed below. In 2003 Makkai published his unusually constructed autobiography, titled Az erô: szabálytalan életrajz versben és prózában ['The Force: Irregular Autobiography in Verse and Prose'] (see Cooper 2012, on whose title I have riffed in my own title, and to whom I am indebted for some details of Makkai's biography).

Within the world of linguistics Makkai is one of world's major experts on idiom structure of English idioms (Idiom Structure in English, 1972; A Dictionary of American Idioms, 1975-1995; see also his 1978 "Idiomacy as a Language Universal," as well his 2011 "On Redefining the Idiom" which offers a theoretical refinement on his original theories). Makkai has contributed over a hundred linguistics articles to numerous journals, and in 1974 he was the principal founder of LACUS, the Linguistic Association of Canada and the United States (for his full bibliography see "Adam Makkai. Articles" at makkai.org.)

Perhaps the area of Makkai's linguistics research that needs to be singled out for readers of this journal is his work in Ecolinguistics (1992), where he uses ecology of language as a metaphor for the study of interactions between any language and its

(cc) $\mathrm{Br}$

ULLS D-Serle 
Vasvári, Louise O. “Ádám Makkai: Polyglot Linguist, Poet and Literary Translator Between Languages.”

Hungarian Cultural Studies. e-Journal of the American Hungarian Educators Association, Volume 6 (2013):

http://ahea.pitt.edu DOI: 10.5195/ahea.2013.178

environment, i.e., the society" (cf. Fill 1997). Ecolinguistics is also concerned with the rivalry between languages in the mind of multilingual speakers and multilingual societies, which includes topics such as language contact, language interference, planning, and death, and can involve taking up the cause of "small languages," and maintaining and saving linguistic diversity, all of central interest to Makkai as both a linguist and a poet, and as a native speaker of a "small language." Finally, for him ecology of language also includes the study of relations between language and music, as well as between language and other topics in which the study of sentence structure is transcended (Makkai 1990). In this context I vividly recall a very unusual scholarly talk and musical performance I attended several years ago in Budapest where Ádám Makkai and Ágnes Arany Makkai illustrated the interrelationship of music and poetry through a joint poetry reading and piano performance.

While to fellow linguists Adam Makkai is first and foremost a linguist, for readers of this journal it is his work related to Hungarian poetry, both in the original and translation that is likely to be of greatest interest. It must be stressed, however, that his linguistics scholarship, as well as his multilingualism, is never separate from his work as a poet and literary translator, as I hope to make clear in this brief overview. Makkai's first and perhaps most lasting love can be said to be poetry, with his first verses published in Hungary in 1954. He has written original poetry in both Hungarian and English, and he is a translator to and from several languages of his own poetry and that of others, and much of his theoretical work is also written about poetry. In Hungarian he has written hundreds of poems and has published two volumes of original Hungarian poetry in the U.S. (1966, 1971) and has also contributed to several anthologies and has published a collection in Hungary (1991). Makkai is, however, perhaps most renowned-at least outside of the world of linguistic scholarship -as the editor and major contributing translator of In Quest of the Miracle Stag (1996), a 1030-page anthology of Hungarian poetry in English translation. The collection is the only such large scale anthology of Hungarian verse, and includes the work of 78 authors and a selection of folk poetry and verse by anonymous writers. Thomas Cooper (2012: 78) has rightly called this collection "one of the most prominent significant contributions to Hungarian literature in English," while the Nobel Prize winning Irish poet, Seamus Heaney in The Times Literary Supplement (Dec. 5, 1997) judged the anthology "a revelation, an inundation...an education in a great corpus of poetry insufficiently known in English." As Audrey Lumsden-Kouvel (1998: 208) explains in her review of In Quest, the new worlds revealed in this collection of Hungarian poetry are indeed broad and for most readers, exotic [because] as Lászlo Cs. Szabó remarks in his useful Postlude, the "A Nation and Its Poetry," the Hungarian language has remained "inaccessibly unique." Lumsden-Kouvel also quotes the renowned critic Edmund Wilson to the effect that Hungarian poetry is "so rich and strange that the language is worth learning for the sake of its poetry alone."

Of very special importance is that, in a number of cases in the Miracle Stag, several translations of the same original are presented, which arguably is the only way to judge poetry in translation. Compare the work of Rainer Schulte (1988), Editor-in-Chief of Translation Review, who is able to illustrate the importance of such a method in a two-page article by critically comparing multiple translations of "The Panther" by Rainer Marie Rilke. In later works Schulte $(1994: 1,2002)$ also points out that one of the major tools to achieve 
Vasvári, Louise O. “Ádám Makkai: Polyglot Linguist, Poet and Literary Translator Between Languages.”

Hungarian Cultural Studies. e-Journal of the American Hungarian Educators Association, Volume 6 (2013):

http://ahea.pitt.edu DOI: 10.5195/ahea.2013.178

a thorough reading of a text is the use of multiple translations, thus providing insight into gray zones of ambiguity as well as multiple and interpretive perspectives, concluding that no reading of a poem can be more intense than that which proceeds through the study of multiple translations. Ironically, or perhaps appropriately, Miracle Stag was also reviewed in Hungarian Studies, simultaneously, within one composite article, by four different reviewers (Richard Aczel, Christof Scheele, Thomas Cooper, Mihály Szegedy-Maszák 2000). These scholars each give very different interpretations of the anthology, sometimes perhaps unfairly critiquing the quality of the translations, losing sight of the fact that one of the aims of the volume, besides providing a vast panoramic historical overview of Hungarian poetry, not attempted in previous collections like those of Miklos Vajda (1977) or Thomas Kabdebo (1976), is to offer multiple translations when such are available.

Another example of how multiple translations work to offer a richer understanding of the original poem is Makkai's (2002) study of translations of a poem by Attila József, Születésnapomra ['For My Birthday'], a poem generally considered untranslatable because of the great amount of wordplay it contains.

Makkai first illustrates the concept of multiple translations by discussing Goethe's Ein Gleiches translation into various languages. He then (from page 12) discusses six different translations of the same poem by József, rendered by the following translators: István Fekete, Anton Nyerges, Earl M. Herrick, Makkai himself, Frederick Turner, and Peter Zollman. Makkai first presents the translations rather than the original and asks his audience (the paper was first presented orally at the LACUS conference to fellow linguists) to attempt to reconstruct the original in their imagination from the multiple translations (those readers interested in translations of Attila József might also further consult Scheele 1997, Hargitai 1999, and Abondolo 2006).

A very special-one can even say "curious" and experimental but very entertaining-work by Makkai is Cantio Nocturna Peregrini Aviumque (1996). Subtitled $A$ Puzzle in Eight Languages, with the subtitle actually written out in eight different languages, the work is, in addition to being both an eight-language poetry book containing scholarly essays, a two-hundred-and-fiftieth-birthday tribute to Goethe, one which, according to Makkai, conveys what he has learned from thirty-five years of being a linguist and fifty of being a poet. As Makkai states on the jacket blurb of the volume, since the year 1999 was not only the end of a much-troubled century but also the end of a millennium, he saw an irresistible challenge in comparing Goethe's philosophy to modern literary theories and to General Linguistics. However, instead of writing a theoretical study, he was inspired to write what he calls anasemic variations, or poetic reinterpretations, of Goethe's well-know poem "Ein Gleiches" as, to quote the author again, a "passionate attack against bad poetry" (on the concept of anasemic poetry see also Makkai 1989). The varied material in Cantio Nocturna includes twelve rewrites in eight languages by Makkai of Goethe's poem in each of the following languages: German, English, French, Spanish, Russian, Hungarian, Italian, and Latin (with all the texts also appearing in English prose). Each variation is a poem in itself but all together they form 96 variations of the original, all connected by themes of death, forest, being a pilgrim, and the potentiality of uplifting human consciousness to higher spheres. In these "anasemic variations" Makkai appropriates famous lines by Dante, Petrarch, Ungaretti, Rimbaud, Baudelaire, Mallarme, Pushkin, Neckrasov, Lermontov, Martí, García Lorca, Nietzsche, Schiller, and many more. Through 
Vasvári, Louise O. “Ádám Makkai: Polyglot Linguist, Poet and Literary Translator Between Languages.”

Hungarian Cultural Studies. e-Journal of the American Hungarian Educators Association, Volume 6 (2013):

http://ahea.pitt.edu DOI: 10.5195/ahea.2013.178

the various poetic and theoretical sections of the volume, Makkai manages to successfully link Goethe's philosophy to modern literary and linguistic theories, doing so in an entertaining fashion. For a fuller overview, see Gerlinde Ulm Sanford's review (2000: 43), one in which she points out that this remarkable book "evokes numerous questions, for example, about textual relationships, about the possibility or impossibility of translating from one language into another, about what constitutes good or bad poetry." Another reviewer, Astradur Eysteinsson, who describes Cantio Nocturna as a "polyglot labyrinth... funhouse," also points out that Makkai's project raises a host of questions about the degrees and concepts of textual relationships, particularly about intertextuality. While Cantio is a veritable tour-de-force of poetic multilingualism, my favorite piece is, in some respects, the article "The Splendor and Decadence of Modern Linguistics" (191-201), a piece almost hidden away in the volume, which gives a masterly overview of linguistics in the twentieth century and of its not always positive relationship to translation theory and practice.

It is perhaps appropriate in this tribute to Adam Makkai, linguist, poet, and translator, to give him the last word on what he believes is the task of the translator of poetry: "I have come to view the translation of poetry as unselfish acts of heroism, studies in futility, love's labor lost, rampant insanity, an unnecessary expenditure of time, money and energy, and yet something that is ultimately well worth the effort, provided we accept the possibility of multiple translations" (Makkai 2002: 12).

\section{Works Cited}

Abondolo, Daniel. 2006. “Attila József's 'Szürkület' and Covert Translation.” Central Europe 4.2: 147-158.

Richard Aczel, Christof Scheele, Thomas Cooper, Mihály Szegedy-Maszák. 2000. Reviews of Miracle Stag. Hungarian Studies 14.1: 127-136.

Cooper, Thomas. 2012. "Poet Between Two Languages. Ádám Makkai.” Hungarian Review 6: 98-101. www.ceeol.com

Eysteinsson, Astradur. 1997. "Review of Cantio Nocturna Peregrini Aviumque”. Exchanges 8: 118-122.

Fill, Alwin, 1997. "Ecolinguistics as a European Idea." The European Legacy: Towards a New Paradigm 2.3: 450-53.

Hargitai, Peter. 1999. Perched on Nothing's Branch; Selected Poetry of Attila József. Buffalo: White Pine P.

Kabdebo, Thomas. 1976. Hundred Hungarian Poems. London: Albion P.

Lumsden-Kouvel, Audrey. 1998. "Review of The Miracle Stag." Comparative Literature Studies 35.2: 208-213.

Makkai, Adam. 1989. “Anasemiotic Multilingual Poetry: Fact or Fiction? Hungarian Studies 5.1: 167-190.

1990. "Systems of a Simultaneous Awareness: Towards a 'Musical Linguistics." LACUS Forum 16: 19-60 www.lacus.org .1992.Ecolinguistics: Towards a New Paradigm for the Science of Language? London: Frances Pinter. 
Vasvári, Louise O. “Ádám Makkai: Polyglot Linguist, Poet and Literary Translator Between Languages.”

Hungarian Cultural Studies. e-Journal of the American Hungarian Educators Association, Volume 6 (2013):

http://ahea.pitt.edu DOI: 10.5195/ahea.2013.178

. ed. 1996 [2000]. In Quest of the 'Miracle Stag:' The Poetry of Hungary.

Chicago-Budapest: Atlantis; Budapest: Corvina-Szivárvány. 1996 [1999]. Cantio Nocturna Peregrini Aviumque: A Puzzle in Eight

Languages. Chicago: Atlantis-Centaur. . 2002. "Presidential Address: The Mystery of Translation." LACUS Forum 29:

5-21. www.lacus.org 2003. Az erő: szabálytalan életrajz versben és prózában [The Force: Irregular Autobiography in Verse and Prose. Budapest: C.E.T.) 2011. "On Redefining the Idiom." http://www.lacus.org/volumes/36)

Sanford, Gerline Ulm. 2000. Review of Cantio Nocturna Peregrini Aviumque. Translation Review 60.

Scheele, Georg. 1997. "The Poetry of Attila József in English Translation." Hungarian Studies 12.1-2: 119-124.

Schulte, Rainer. 1988 “Multiple Translations: An Interpretive Perspective.” Translation Review 28: 1-2.

Schulte, Rainer. 1994. Comparative Perspectives: Anthology of Multiple Translations. Washington DC: American Heritage Publications.

Schulte, Rainer. 2002. The Geography of Translation and Interpretation: Traveling Between Languages. Lewiston: Edwin Mellen P.

Vajda, Miklos. 1977. Modern Hungarian Poetry. New York: Columbia UP. 